\title{
Dialyzer reuse; Effect on efficiency and biocompatibility
}

\author{
Atef H Huzayin *, Hayam A El Aggan *, Mohamed M Rizk ** and Ahmed F El Koraei * \\ Depatments Internal Medicine (Nephrology Unit) * and Clinical Pathology Departments **, Faculty of Medicine - \\ University of Alexandria, Egypt.
}

\begin{abstract}
Fifteen patients on maintenance haemodialysis were studied before and after reuse of cuprophane hollow-fiber dialysers to assess its biocompatibility and efficiency.

There was a significant increase in hematocrite value and hemoglobin level by the end of dialysis. Also, there was a significant decrease in total leukcocytlc, (neutrophilic \& eosinophilic) and platelet counts with a peak at 15 minutes after the start of dialysis, then there was a gradual increase till the end of dialysis reaching near the predialysis value.

These changes occurred both in the first use and the reuse sessions. The decrease in the neutrophilic count with the reused dialyzer was significantly less compaired to first use dialyzer.
\end{abstract}

The terminal complement complex (TCC) significantly increased and reached its maximum after 15 minutes, then it began to decline till the end of the dialysis. Similarly, these changes were significantly less in the reuse dialyzers. No correlation was found between the changes of the TCC and the decrease in different cellular elements.

There was an increase in plasma bicarbonate and $\mathrm{pH}$ by the end of dialysis. Also, hypoxia and hypocapnea occured shortly after the start of dialysis session with acetate dialysate, but they returned to their predialysis values at the end of both dialysis sessions. This can be attributed to the loss of carbon dioxide into the dialysate with subsequent hypoventilation.

The clearances of urea, creatinine and phosphorus showed insignificant difference between the new and reused dialyzers at zero and $4 \mathrm{hr}$ time with significant decrease by the end of dialysis in both dialysis session. This could be explained by kceping the surface area of the reused dialyzers within the acceptable valucs $(80-100 \%)$ of the first use dialyzer.

It can be concluded that reused dialyzers were to some extent morc hemocompatible than the first use dialyzcrs. Complement activation is not the sole factor for the biocompatible reactions during dialysis. Reuse of dialyzers can be a safe procedure by adopteding appropriate stcrilization, reprocessing and storage techniques and limited number of reusc.

\section{Introduction}

Chronic haemodialysis is one of the major theraputic modalities for chronic renal failure patients. Many factors determine the costs and it is important to be reduced [1]. The pricc of dialyzers constitute the major part of dialysis costs. Rcusc of dialyzers was instituted in 1964 |11.

Dialysis biocompatibility, can be defined as the sum of specific and non specific interactions between blood and the artificial materials of the dialysis circuis [2].

During contact of blood with the dialysis membranes, a variely of mediator are activated. These may be soluble or cellular [3]. The former include peptides, fatly acids or amines. Among these substances are, complement components (C) fibrinogen, coagulation factors, prostaglandins, thromboxane, leukotriens, kinins and histamine |31.

The cellular factors include, platelets which release thromboxane, neutrophils which lead 10 relcase of proteases and toxic oxygen radicals. While 
monocyte and lymphocyte activation lead to production of interleukln I and lymphokines respectively [3]. Activation of the complement system occurs by either the classical or the alternative pathway. The classical pathway is initiated with the first component of complement $(\mathrm{Cl})$ and the alternative pathway is initiated with the third complement componel (C3), with subsequent activation and assembly of the terminal complement components (C6, C7, C8) and multiples of $\mathrm{C} 9$ are associated with $\mathrm{C} 5 \mathrm{~b}$ to form multimolecular memebrane attack complex (C.5b-9) or the terminal complcment complex (TCC) [4].

The C5b-9 complex can react with plasmatic Sprotcin, a scavenger which keeps the complex in fluid phasc. 141 .

The aim of this work was to study the effect of reuse of hollow fiber dialyzers on dialysis efficiency and biocompatibility.

\section{Materials and methods}

This study included 15 paticnts $(8$ males and 7 females) with end stage renal disease on maintenance haemodialysis (HD) admitted to the Nephrology and Dialysis Unit at Alcxandria University Hospital. Their ages ranged between 22-60 year with mean of $41+19$ years and the duration of dialysis ranged between 32 88 months with a mean $60 \pm 28$ months.

We cxcluded patients with autoimune diseases, intercurrent infection and those recciving immunosuppresive therapy.

All patients were subjected to full history and thorough clinical cxamination to define the symptoms and signs of dialyzer reaction as headache, chest pain, dyspnca, vomiting, angioneurotic ocdema, rash and muscle cramps.

\section{Dialysis procedure}

In the first usc scssion the dialyzer used was the hollow fiber with cuprophanc membrane and $1 \mathrm{~m}^{2}$ surface area.

In the reuse session the dialyzer was reprocessed for onc reuse only using ECHO reuse system. Sodium hypochlorite $(5.25 \%)$ was used for cleaning and dialox solution (peracetic acid $4.5 \%$, acctic acid $6 \%$, and hydrogen peroxide $28 \%$ ) as a disinfectant and cleancr.

The dialysate was acclatc dialysatc composed of sodium $134 \mathrm{mEq} / \mathrm{l}$. polassium $2 \mathrm{mEq} / \mathrm{l}$, calcium 4 $\mathrm{mEq} / \mathrm{l}$, magnesium $1.5 \mathrm{mEq} / \mathrm{l}$, chloride $105 \mathrm{mEq} / \mathrm{l}$, and acclate $36.6 \mathrm{mEq} / 1$.

Dialysatc flow ratc was $500 \mathrm{ml} / \mathrm{min}$, the flow of blood pump was at $250 \mathrm{ml} / \mathrm{min}$. The transmembrane pressure (TMP) was adjusted at $100 \mathrm{mmHg}$ and venous pressure ranged from $50-80 \mathrm{mmHg}$. Water used for dialysate was purified and treated by sand filter, carbon filter, sofiner, reverse osmosis and bacterial filter. The duration of this dialysis session was four hours, three times weekly.

\section{Collection of samples}

All blood samples were collected at zero time before dialysis, then at 15 minutes and 4 hours from the start of dialysis. The samples were stored at $-70 \mathrm{OC}$.

\section{Laboratory studies}

1. The following tests were done for all blood samples:

a) Hemoglobin (HB) and haematocrit (Ht) [5].

b) Platelet count, total and differential leucocytic count by electronic counter. Coulter $\mathrm{T} 540^{+}$[5].

c) Arterial blood gas analysis: partial arterial oxygen and carbon dioxide pressure $(\mathrm{PaO} 2$, $\mathrm{PaCO} 2)$, plasma bicarbonate $(\mathrm{HCO} 3)$ and $\mathrm{pH}$ [6].

2. The efficiency of the dialysers at the first use and reuse sessions was estimated twice; at the start and at the end of dialysis ( $4 \mathrm{hr}$ ). This was achieved by measuring urea, creatinine and phosphate clearances [6.7].

3. The biocompatibility of the dialyzer was measured by estimation of serum level of the end product of complement activation C5b-9 complex using. Enzyme- Linked Inununosorbent Assay (ELISA) technique. The kit was purchascd from QUIDEL, San Diego, USA [8]. This kit was used for the quantitification of SC5b-9. It was a three-step procedure utilizing: (1) a microassay plate coated with a mouse monoclonal antibody which binds specifically to SC5b-9, (2) Horse radish peroxidase (HRP) conjugated antibodies to antigens of SC5b-9, and (3) a chromogenic substrate [8].

Calculation of the results was done using the standard currve: The absorbance was at 405 value for each SC5b-9 standard (y) and the assigned nanograms of SC5b-9 per $\mathrm{ml}(\mathrm{ng} / \mathrm{ml})$ value for the standards $A, B$ and $C$ were used to establish the standard curve. The best fit line was drawn on the provided graphic paper. The $\mathrm{ng} / \mathrm{ml}$ concentration for each diluted sample then was read on the $\mathrm{X}$-axis for each corresponding absorbance 405 value obtained.

\section{Results}

During the first use and the reuse sessions none of the patients had any reaction. 
The surface area of the reused dialyzer ranged between $80-100 \%$ with a mean of $96 \%$ from the intial surface area of the first used dialyzer.
Hemoglobin and hemotacrit values increased significantly during both first use and reuse sessions, reaching its highest value at the end of dialysis (table 1).

Table 1. Mean percent change $\pm S D$ and statistical comparisons of hematocrite $(\%)$, hemoglobin $(\mathrm{g} / \mathrm{dl})$, platelets $\left(X 10^{3}\right.$ cell/1mm $\left.{ }^{3}\right)$ and terminal complement complex (SC5b-9ng/ml) in the first use and reuse at different periods of dialysis scssion.

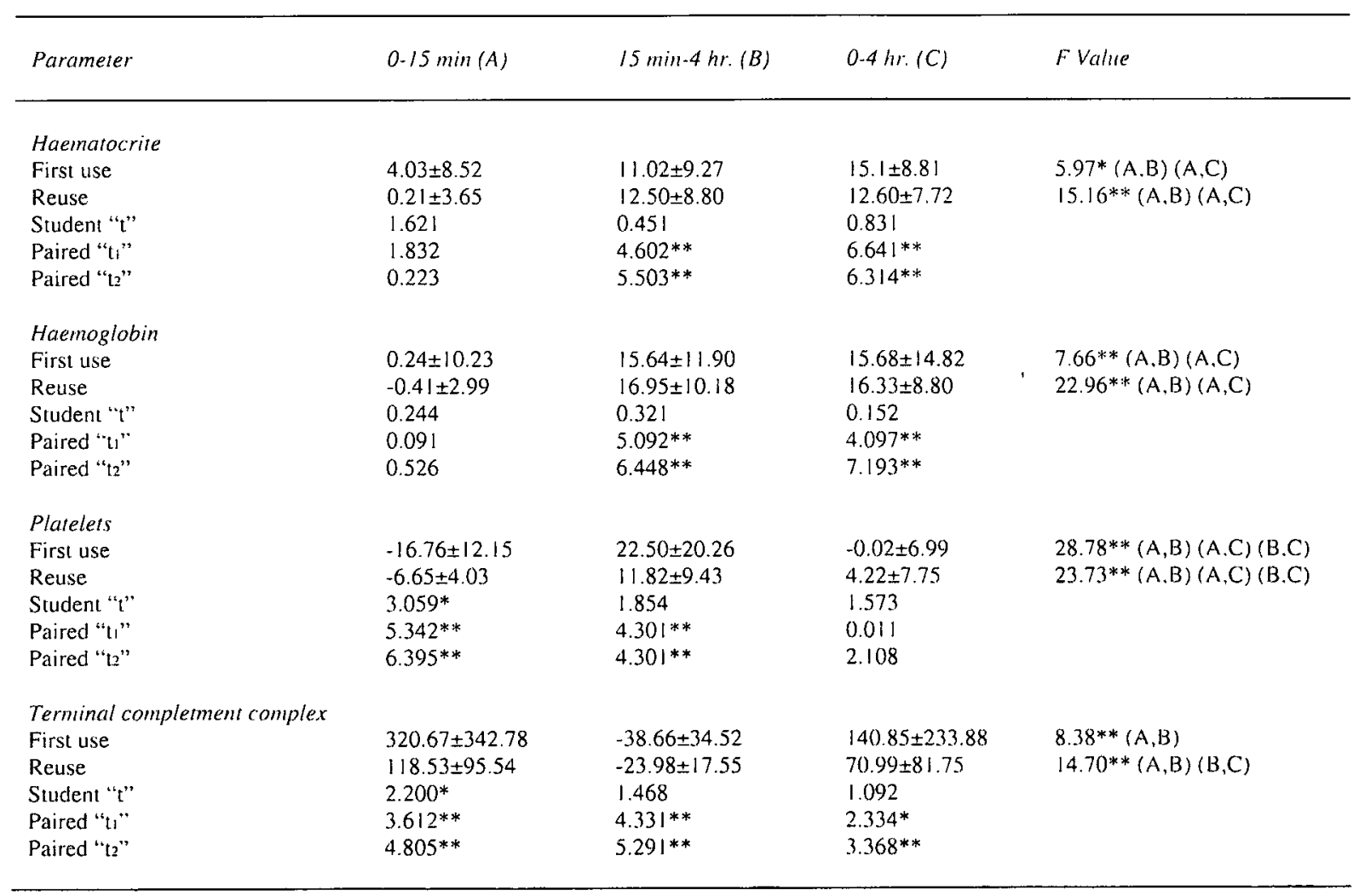

$t=$ Paired $t$ of the percent change at different periods in the first use session.

$12=$ Paired $t$ of the percent change at different periods in the reuse session.

$*$ Significant $P$ value at $5 \%$ level. $\quad * *=$ Significant $P$ value at $1 \%$ level.

The total leucocytic, oesinophilic, neutrophilic and platelet counts, blood gases ( $\mathrm{PaO} 2$ and $\mathrm{PaCO} 2$ ), plasma bicarbonate and $\mathrm{pH}$ showed an early drop, followed by rise to reache near thier predialysis level by the end of the dialysis in both sessions (table 1, 2, 3).

Table 2. Mean percent change \pm SD and staristical comparisons of total leuccocytic ( $10^{4}$ cell/mns) eosinophilic (cell/i-nM3), neutrophilic $\left(\times 10^{3}\right.$ cell/nun $\left.{ }^{3}\right)$ and lymphocytic $\left(\times 10^{3}\right.$ cell/ $\left.\mathrm{mm}^{3}\right)$ counts in the first usc and reuse at different periods of dialysis sessions.

\begin{tabular}{|c|c|c|c|c|}
\hline Parameter & $0.15 \min (A)$ & $15 \min -4 h r .(B)$ & $0.4 \ln r(C)$ & FValire \\
\hline \multicolumn{5}{|c|}{ Total leukocynic count } \\
\hline First use & $-56.35 \pm 17.88$ & $210.32 \pm 186.90$ & $10.00 \pm 32.26$ & $23.97^{* *}(A, B)(A, C)(B, C)$ \\
\hline Reuse & $-45.66 \pm 21.74$ & $177.44 \pm 151.33$ & $25.45 \pm 31.43$ & $23.90 * *(A, B)(A, C)(B, C)$ \\
\hline Student "t" & 1.485 & 0.534 & 1.332 & \\
\hline Paired "tu" & $|2.20| * *$ & $4.351^{* *}$ & 1.205 & \\
\hline Paired "t2" & $8.114^{* *}$ & $4.545^{* *}$ & $3.137 * *$ & \\
\hline \multicolumn{5}{|c|}{ Eosinophilic count } \\
\hline First use & $-72.88+27.44$ & $160.99 \pm 182.99$ & $3.34 \pm 45.19$ & $17.65^{* *}(A, B)(A, C)$ \\
\hline Reuse & $-48.43 \pm 45.06$ & $334.66 \pm 283.71$ & $34.50 \pm 72.32$ & $20.83^{* *}(A, B)(A, C)$ \\
\hline Student " $t$ " & 1.795 & 1.992 & 1.415 & \\
\hline Paired "t1" & $10.286^{* *}$ & $3.407 * *$ & 0.286 & \\
\hline Paired "t 2 " & $4.162 * *$ & $4.568 * *$ & 1.847 & \\
\hline
\end{tabular}




\begin{tabular}{|c|c|c|c|c|}
\hline \multicolumn{5}{|c|}{ Neutrophil count } \\
\hline Studenl "i" & $2.159 *$ & 2.142 & 2.056 & \\
\hline Paired "12" & $15.750 * *$ & $6.886^{* *}$ & $2.610^{*}$ & \\
\hline \multicolumn{5}{|c|}{ Lymphocyric coum } \\
\hline Student "t" & 1.163 & 1.520 & 0.058 & \\
\hline Paired "II" & 0.912 & 2.008 & 1.874 & \\
\hline Paired " 2 " & 0.755 & $2.696^{*}$ & $2.625^{*}$ & \\
\hline
\end{tabular}

Abbreviations as table 1.

Table 3. Mean percent change $\pm \mathrm{SD}$ and statistical comparison of partial arterial oxygen and carbon dioxide pressures ( $\mathrm{PaO} 2$, $\mathrm{PaCO} 2 \mathrm{~mm}$ $\mathrm{lig}$ ). plasma bicarbonatc ( $\mathrm{HCO} 3 \mathrm{mEq} / \mathrm{L}$ ) and $\mathrm{pH}$ in paticnts on maintenance hemodialysis in the first use and reuse at different periods of dialysis sessions.

\begin{tabular}{|c|c|c|c|c|}
\hline Parameter & $0.15 \min (A)$ & $15 \min -4 \mathrm{hr} .(B)$ & $0-7 \mathrm{hr} \cdot(\mathrm{C})$ & F Value \\
\hline \multicolumn{5}{|l|}{$\mathrm{PaO}_{2}$} \\
\hline First usc & $-17.71 \pm 9.39$ & $17.02 \pm 10.14$ & $-4.15 \pm 9.84$ & $47.89 * *(A, B)(A, C)(B, C)$ \\
\hline Reuse & $-15.82 \pm 8.22$ & $20.88 \pm 17.38$ & $1.00 \pm 12.16$ & $29.33^{* *}(A, B)(A, C)(B, C)$ \\
\hline Student "I" & 0.596 & 0.741 & 1.281 & \\
\hline Paired "lı" & $7.301 * *$ & $6.494 * *$ & 1.635 & \\
\hline Paired "12" & $7.458 * *$ & $4.656^{* *}$ & 0.311 & - \\
\hline \multicolumn{5}{|l|}{$P u C o$} \\
\hline First use & $-28.91 \pm 19.57$ & $47.85 \pm+5.62$ & $-2.15 \pm 15.62$ & $25.22 * *(A, B)(A . C)(B . C)$ \\
\hline Reusc & $-13.4 .3 \pm 13.55$ & $31.71 \pm 24.31$ & $12.28 \pm 18.66$ & $20.54^{* *}(\mathrm{~A} . \mathrm{B})(\mathrm{A}, \mathrm{C})(\mathrm{B}, \mathrm{C})$ \\
\hline Student ". & $2.521^{*}$ & 1.243 & $2.315^{*}$ & \\
\hline Paired "l," & $5.721 * *$ & $4.063 * *$ & 0.532 & \\
\hline Paired "t2" & $3.834 * *$ & $5.056 * *$ & $2.545^{*}$ & \\
\hline \multicolumn{5}{|c|}{ Plasma HCO, } \\
\hline Firsl usc & $-6.88 \pm 11.28$ & $36.78 \pm 21.45$ & $25.77 \pm 14.12$ & $29.49 * *(A . B)(A, C)$ \\
\hline Reuse & $-2.28 \pm 5.71$ & $31.58 \pm 14.14$ & $28.33 \pm 14.03$ & $36.68 * *(A, B)(A, C)$ \\
\hline Student "." & 1.444 & 0.781 & 0.525 & \\
\hline Paired "॥" & $2.362^{*}$ & $6.465^{* *}$ & $7.061 * *$ & \\
\hline Paired "ta" & 1.541 & $8.561^{* *}$ & $7.842 * *$ & \\
\hline \multicolumn{5}{|l|}{$P l l$} \\
\hline First use & $-0.12 \pm 0.67$ & $2.04 \pm 0.273$ & $1.92 \pm 0.95$ & $34.7 I^{* *}(A, B)(A, C)$ \\
\hline Reuse & $-0.29 \pm 0.75$ & $2.19 \pm 0.61$ & $1.89 \pm 0.82$ & $50.93^{* *}(A, B)(A, C)$ \\
\hline Student "I" & 0.676 & 0.621 & 0.080 & \\
\hline Paired "t" & 0.678 & $10.711 * *$ & $7.792 * *$ & \\
\hline Paired "l2" & 1.491 & $13.832 * *$ & $8.914^{* *}$ & \\
\hline
\end{tabular}

Abbreviations as table 1 .

There was a significant increase in the TCC (SC5b-9) level at 15 minutes then it declined till the end of dialysis, although it rcmained higher than the predialysis level. This occured both at the first use and reuse sessions (table 1).

The decrease in the neutrophil and platelet counts and the increase in S5b-9 level wcre significantly less in the reusc session than the first usc session (table 1,2). Urea, creatinine and phosphorus clearance decreased significantly by the end of dialysis ( $4 \mathrm{hrs}$ ). This decrease was insignificantly different comparing the first use and reused dialyzers (table 4).

There was a significant positive correlation between the $\%$ changes of the surface area after reuse and urea and creatinine clearance at zero time $(r=0.686$, 0.700 respectively) and at $4 \mathrm{hr}$ time with creatinine clearance only ( $r=0.584)$.

No correlation was found between the \% change of TCC (Sc5b-9) and the neutrophilic count at both the first use and the reuse session at $0-15 \mathrm{~min}$ and 15 
$\min -4 \mathrm{hr}$ times. $(r=-0.232,0.100,-0.331,-0.054$ respectively).

Table 4. Mean $\pm S D$ and statistical comparisons of urea, creatinine and phosphorous clearances ( $\mathrm{nil} / \mathrm{min}$ ) at the bcginning and the end of the first use and reuse sessions.

\begin{tabular}{|c|c|c|c|c|}
\hline Parameter & $O \min$ & $4 h r$. & 0 mint th: \%c change & Paired " 1 " \\
\hline \multicolumn{5}{|c|}{ Urea Clearance } \\
\hline First use & $128.89 \pm 16.32$ & $107.53 \pm 18.22$ & $-15.86 \pm 13.56$ & $4.531 * *$ \\
\hline Reuse & $115.53 \pm 12.23$ & $96.00 \pm 16.61$ & $-16.73 \pm 11.91$ & $5.442 * *$ \\
\hline Student " $\mathrm{t}$ " & $2.512^{*}$ & 1.810 & 0.191 & \\
\hline \multicolumn{5}{|c|}{ Creatinime clearance } \\
\hline First use & $134.13 \pm 19.25$ & $119.80 \pm 14.16$ & $-10.03 \pm 8.39$ & $4.622 * *$ \\
\hline Reuse & $124.80 \pm 16.60$ & $111.27 \pm 19.24$ & $-10.89 \pm 9.26$ & $4.552^{* *}$ \\
\hline Student ":" & 1.425 & 1.385 & 0.271 & \\
\hline \multicolumn{5}{|c|}{ Phosphorous clearance } \\
\hline First use & $114.78 \pm 25.32$ & $103.80 \pm 14.86$ & $-6.54 \pm 17.92$ & 1.411 \\
\hline Reuse & $104.20 \pm 20.46$ & $95.13 \pm 32.15$ & $-8.08 \pm 31.87$ & 0.987 \\
\hline Student "i" & 1.261 & 0.951 & 0.165 & \\
\hline
\end{tabular}

Abbreviations as table 1 .

\section{Discussion}

This study showed that the TCC orC (SC5b-9) as one of the parameters of biocompatibility was significantly increased early in both dialysis session which was less in the reuse than the first use session denoting that reused dialyzers were more biocompatible, although still activate the complement cascade to a certain extent.

These results agree with the results of Deppisch et al [8] who first describe the use of TCC as sensitive index of bioincompatibility in haemodialyzed patients.

The other complement (C) components specially $\mathrm{C} 3 \mathrm{a}$ and $\mathrm{C} 5 \mathrm{a}$ were also found by many authors to be increased during dialysis using unsubstituted cellulose dialyzers than the synthetic modified cellulose or in the reused dialyzers [9-12].

The increase in complement components during dialysis reflect the balance between its activation and clearance. Also, the subsequent decline could be related to deposition of $C$ fragements on the activating sites of the dialyzer membrane surface or loss in the dialysate [9-12].

Both the SC5b-9 and peripheral leukocyte are not expected to penetrate the dialyzer membrane, so measurement of TCC may be an index of biocompatibility, complementary to and independent of the C-anaphylatoxins [8].

The complement system stimulates nucleated cells with the release of different cytokines [3,13].

Dialysis associated leukopenia and thrombocytopenia were studied as parameters of bioincompatibility. Both occurred in the first use and the reuse sessions but was less with the reused dialyzer than with the first use dialyzer, this also denote that reused dialyzers are morc biocompatible than the new onc. Hemodialysis induced neutropenia was also observed and reporicd by many authors || $3-18 \mid$.

Neutropenia is associated with increased expression of cell surface adhesion molccules that was supposed to be stimulated by complement activation [19].

Himmelfarb et al, [19] concluded that MAC-1 expression induce changes in granulocyte cell surface with subsequent the development of granulocytopenia with their adherence to the dialysis membrane and sequestration in the pulmonary capillaries, but it is not sufficient to maintam it.

The subsequent reversal of the ncutropenia was secondary to the decrease in the CAM-I expression with down regulation of another adhesion receptors of the selectin family (LAM-1) with their shedding from their attaching surface receptors to return back to the circulation.

The absence of correlation between TCC changes and changes in blood count, may suggest that complement was not the solc mediator of ncutropenia and changes in other cellular factors. Other factors such as cytokines, chemotactic factors and lipopoly-saccharides may be important $|20,2| \mid$. Studics done on the effect of reprocessing to improve dialysis induced ncutropenia yiclded controversial results and this can be explained by the different reuse methods and the type of membranes studied $\{9,10,12,181$.

The beneficial effect of reusc had been attributed to the protective coating of the surface of dialyzer membrane during its first use, particularly the 
fixation of $\mathrm{C} 3 \mathrm{~b}$ on cuprophane, which could block complement activating sites $[9,12]$.

Heparin induced thrombocytopenia (MT) had been reported in $5 \%$ of (22) patients with endothelial cell injury.

The increase in $\mathrm{Hb}$ and $\mathrm{Ht}$ values by the end of dialysis could be attributed to the relative hemoconcentration due to ultrafiltration. This was supported by the finding of negative correlation at end of dialysis between changes of atrial natiuretic peptide (ANTI) and blood volume and Ht [23].

The occurrence of hypoxemia and hypocapnea early in dialysis was the subject of many investigatious, |14,24,25].

Hypoxemia and the early decrease of plasma $\mathrm{HCO} 3$ and $\mathrm{pH}$ were attributed to many factors including alveolar hypoventilation following carbon dioxide losses into the dialysate (CO2 unloading). intrapulmonary leukostasis, changes in the respiratory quoteint during acctate metabolism and direct effect of acclate on the central respiratory center. The subsequent rise of these parameters was related to the correction of acidosis by acetate buffer in the dialysate $|24,25|$.

The efficiency of the rcused did not differ from that of the first usc dialyzcr and the decrease of efficiency by the end of dialysis was the same in both dialysis scssions. This could be explained by kceping the surface area of the reused dialyzer which was within the acceptable valuc $(80-100 \%)$ of surface arca of the first use dialyzer $|26|$.

In this study none of the patients had symptoms or signs of dialyzer reactions neither in the first use nor in the reuse sessions. This could be partly altributed to proper rinse of the fresh hollow fiber dialyzer with salline before dialysis. This process could wash out any traces of the steraliser used which was the cthylene dioxide (ETO). It was claimed that it can cause type 1 hypersensitivity reaclion and anaphylaxis |27-29|.

Controversial results were shown by different studies due to the use of different techiniques of sterilization and / or cleaning of the dialysers during reuse process 110, 28-311.

Septicemia and endotoxemia had been also reported with reused dialysis $[1,11,21\}$.

Underdialysis had been reported with the reuse dialyzer, bul could be duc 10 many causes including improper lechnique of resue, crrors in selting blood flow, blood access recirculation and short dialysis duration $|32,33|$.

We can conclude that following appropriate procedures, implementation of quality assurance systems and close monitoring of all proccolures, dialyser reuse is safe, ensures effective therapy and provides economic benefil.

\section{References}

1. Victor E, Pollak K. Shashi K. Repeated use of dialysers is safe: long term observation on morbidity and mortality in patients with end stage renal disease. Nephron 1986: 42: 217 23.

2. Grtrland I-IJ. Davison AM. -llansen S. Valek A. Definitions and terminology in blocompatibility. Nephrol Dial Transplant 1994: 9 (Suppl 2): 4-10.

3. Glassoch RJ. General concepts of immuno pathology. In: Massry SG. Glassoch RJ eds. Texibook of Nephrology 3rd Ed. Baltimore. Philadelphia, London: Williains and Wilkins 1995: 1: 623-6.

4. Johnson R. Complement aclivation during extracorporeal therapy: biochemistry, cell biology and clinical relevance. Nephrol Dial Transplanı 1993: 8 [Suppl 2]: 57 63.

5. Dacic J. Lewis SM. Practical Hematology 7 th Ed. Edinburgh, London. Melboume: Churrchill Livingstone 1991, 55-8, 6772.

6. Burtis CA. Ashwood ER. Teitz textbook of clinical chemistry. 2nd Ed. Philadelphia: Saunders VY'B company 1994. 1393-6. 1530. 1533-6.

7. Dryer RL. Routli JJ. Determination of serum inorganic phosphorus: stand methods. Clin Chem 1963. 4: 191

8. Depiscli R. Vera S, Jurgen B. Fluid phase generation of terminal complement complex as a novel index of blolncompatibility. Kidney In 1990: 37: 696-706.

9. Bingel M. Slialdon S. Schulze M. Comparative siudy of C5a plasma levels with different haemodialysis membranes. Nephron 1989. 51: 320-4.

10. Westliuyzen J. Foreman K. Felming SJ. Effect of dialyzer reprocessing with renalin on serum beta $\sim 2$ microglobulin and complement activation in haemodialysis patients. Amer J Nephrol 1992. 12: 29-36.

11. Bergnian TI, Daugirdas JT. Ing TS. Complications during hemodialysis. In: Daugirdas JT. Ing TS eds. Handbook of Dialysis 2nd Ed. Boston. Neu York. Toronto, LondonLitle. Brown and Company 1994: 149-67.

12. Cliting AK. Blocompatibility of dialysis membranes practical considerations. Nephrol Dial Transplant 1994: 9 [Suppl 2] $139-47$.

13. Kisarek A. Koziot M. Phagocytic ftmction of neutrophils diiring dialysis in relation to some immunological findings. Nephrol Dial Transplant 1991: 3: 31-4.

14. Hakim RM, Lowrie EG. Effect of dialyzer reuse on leukopenia. hypoxemia and total haemolytic complement system. Trans Am Soc Artif. Organs 1980: 26: 159-63.

15. Addonisio VP. Colman RW. Plateles and extracorporeal circulation. Blonaterials 1982: 3: 9-15.

16. Hakim RM, Schafer AL llemodialysis associated platele aclivation and thrombocytopenia. Am J Med 1985: 575-80.

17. Clicung AK, Holnolı M, Gilson J. Adherence of neutrophils to hacmodialysis membranes, role of complement receptors. Kidney InI 1991; 40: 1123-33.

18. Cases A, Reverter JC, Escolar G, Reverter L, Ordians A Platcled activation in hemodialysis, influence of dialysis membranes. Kidney !nt 1993:43 |Suppl +11: 217-20.

19. Ilimmelfarb J, Zaoui P, ll'akim R. Modulation of granulocyle $L A M-1$ and $C-1$ during dialysis: A prospective, randomled controlled trial. Kidncy Int 1992; 41: 388-95.

20. Rolliclin R, Grajkowsi $M$. Oneil $M$. Induction of intracellular adhesion molecule-I on primary and continuous cell lines by proinfiammatory cytokines. J Immunol 1988; 141: $1665-9$.

21. Lynn WA, Ratez CR, Golenbock DT. Lipopolysaccharide induced stimulation of CD/Ib/CD 18 expression on ncutrophils. J Immunol 1991; 147-3072-9.

22. Cines DB, Tomask A, Tannenbaum S. Immune endothelial injury in heparin associated thrombocytopenia. $N$ Engl J Med 1987; $316: 581-9$

2. El-Aggan 11, llozayin A, Hassab A. librahim A. Study of plasma atrial natriuretic peptide in patients with chronic renal 
failure and in patients on hemodialysis. Alex Med J 1990:33: 235-39.

24. Tejedor A. Courtear. M, Gougoux A. SiLouis G. Lapierre L. Piette $E$ Hypoxemia during hemodialysis: A critical review of the facts. Am J Kidncy Dis 1988: 11: 281-97.

2 . De-Broe ME. Haemodialysis-induced hypoxemia. Nephrol Dial Transplant 1994- 9 [Suppl 2], 173-5.

26. Gotch FA. Solute and water transport and sterilant removal in reused dialysers. In: Dean D. Wineman RJ. Bemis JA, eds. Guide to Reprocessimg of hemodialyzers- London. Boston: Martinus Nijhoff 1985; 39.

27. Granimer LC. Patterson R. IgE against ethylene oxide altered human serum albumin as an etiologic agent in allergic reactions of hemodialysis patients. Artif Organs 1987; I1: 97-9.

8. Schaeffer RM, schaefer L. Horl WH. Anaphylactoid reacions during hemodialysis. Clin Nephrol 1994-42 [Suppl 1]-. 4-4-7.

29. Vanholder R, Noes L. De Smet R. Ringoirs S. Development of anti-N-like antibodies during formaldehyde inspitic of adequatc predialysis rinsing. Am J Kid Dis 1988. 11: 477-80.
30. David AP. Coiisuelo MB, Stan WW, Bonnic G, Slisan M. Anaphylactoid reactions associated with reuse of hollowfiber hemodialysers and ACE inhibitors. Kidney In 1992; 42-1232-7.

31. Dastgirdas JT, liig TS. First use reactions during hemodialysis: a definition of subtypes. Kidncy lnt 1988: 24 : 3743.

32. Duniler F. Zauwa G, Levin NW. Elfect of dialyzer reprocessing methods on complement aclivation and hemodialy/er related symptoms. Artif Organs 1987. 11: 12834.

33. Slialdon $S$. The influence of dialysis time and dialy zer reuse on survival. Nephrol Dial Transplant 1995; 10 [Suppl 31:5762 .

34. Robert M. Lee WIl Adequacy of dialysis. Kidncy Int 1988: 33 |Suppl 24] 92-9. 